\title{
PENGARUH TEACHER FEEDBACK TERHADAP KEMAMPAUN MURID DALAM PEMBELAJARAN WRITING
}

\author{
Muh. Arief Muhsin \\ Fakultas Keguruan dan Ilmu Pendidikan Univ. Muhammadiyah Makassar \\ email: arief.m@unismuh.ac.id \\ Ika Sastrawati \\ Fakultas Keguruan dan Ilmu Pendidikan Univ. Muhammadiyah Makassar \\ Email: -
}

\begin{abstract}
The research aimed to describe the phenomena of feedback given by the teacher in learning writing. In addition, this study was also described how the response given by the student when receiving feedback from the teacher. The long term goal to be achieved was the improvement of the teaching system so that every educational institution had aimed at teaching concepts to form an intelligent generation. This study was a descriptive qualitative research to be carried out in SMA Muhammadiyah 1 Unismuh Makassar which one of top schools Muhammadiyah. The ability of students in the school had been considered good in communication, but their ability to write was still lacking, especially in terms of grammatical. Therefore, the researcher was described the feedback given by the subject teachers of English subjects at the time of writing, especially when students learned making mistakes in the process of teaching and learning in the classroom . The extent, the teacher can give feedback to the students. The research was described the positive feedback and negative feedback given by the teacher so that it can be information and feedback in the learning process.

Giving feedback subject teachers more English language based situation in the classroom. In writing instructional materials for example, most teachers use an explicit correction and metalinguistic feedback. This is because students are using written language than spoken language. Almost kinds of feedback used in teaching but not as often as with the two types of feedback. The students have different conditions, but most were more likely to agree given feedback after speaking or after making a mistake. The most powerful reason is the lack of experience of students in learning English so want to get direct feedback.
\end{abstract}

Key words: Teacher Feedback, murid, Writing

\begin{abstract}
ABSTRAK
Penelitian ini bertujuan untuk menggambarkan fenomena umpan balik yang diberikan oleh guru dalam belajar menulis. Selain itu, penelitian ini juga menggambarkan bagaimana respon yang diberikan oleh siswa saat menerima umpan balik dari guru. Tujuan jangka panjang yang ingin dicapai adalah peningkatan sistem pengajaran sehingga setiap lembaga pendidikan telah ditujukan untuk konsep mengajar untuk membentuk generasi yang cerdas. Penelitian ini merupakan penelitian deskriptif kualitatif yang akan dilaksanakan di SMA Muhammadiyah 1 Unismuh Makassar yang salah satu sekolah top Muhammadiyah. Kemampuan siswa di sekolah telah dianggap baik dalam komunikasi, tetapi kemampuan mereka untuk menulis masih kurang, terutama dalam hal tata bahasa. Oleh karena itu, peneliti digambarkan umpan balik yang diberikan oleh guru mata pelajaran mata pelajaran bahasa Inggris pada saat menulis, terutama ketika siswa pelajari membuat kesalahan dalam proses belajar mengajar di kelas. Sejauh ini, guru dapat
\end{abstract}


memberikan umpan balik kepada siswa. Penelitian ini menggambarkan umpan balik positif dan umpan balik negatif yang diberikan oleh guru sehingga dapat menjadi informasi dan umpan balik dalam proses pembelajaran.

Memberikan umpan balik guru mata pelajaran situasi berdasarkan bahasa lebih Inggris di dalam kelas. Dalam menulis bahan ajar misalnya, sebagian besar guru menggunakan koreksi eksplisit dan umpan balik metalinguistik. Hal ini karena siswa menggunakan bahasa tertulis dari bahasa lisan. Hampir jenis umpan balik yang digunakan dalam mengajar tapi tidak sesering dengan dua jenis umpan balik. Para siswa memiliki kondisi yang berbeda, tetapi kebanyakan lebih cenderung setuju diberikan umpan balik setelah berbicara atau setelah melakukan kesalahan. Alasan paling kuat adalah kurangnya pengalaman siswa dalam belajar bahasa Inggris sehingga ingin mendapatkan umpan balik langsung.

\section{Kata kunci: Guru Feedback, murid, Menulis}

\section{PENDAHULUAN}

Pada pelajaran bahasa Inggris misalnya, feedback adalah salah satu unsur yang sangat menentukan dalam proses belajar mengajar dan membantu meningkatkan kemampuan siswa. Hal ini sejalan dengan pandangan Paul (2011:8), yang menurutnya feedback; to make decision for identify the error. Dengan demikian feedback akan menjadi pengarah bagi siswa ketika mereka membuat kesalan-kesalan dalam menggunakan bahasa Inggris seperti dalam writing atau menulis.

Untuk mengetahui pengaruh dari feedback dalam proses pembelajaran bahasa Inggris khususnya dalam menulis, peneliti melakukan observasi di SMA Muhammadiyah 1 Unismuh Makassar salah satu sekolah di kota Makassar. Peneliti melakukan observasi awal pada dua kelas yang berbeda dengan guru mata pelajaran yang berbeda pula. Ada salah satu kelas yang tingkat kemampuan siswa rata-rata memiliki kemampuan bahasa Inggris yang baik, dan dapat lulus sesuai dengan KKM yang telah ditentukan oleh guru bidang studi. Sedangkan kelas yang satu tidak merata dan banyak siswa yang tidak tuntas pada mata pelajaran bahasa Inggris.

Oleh karena itu peneliti tertarik untuk mengkaji fenomena tersebut, terutama pada peningkatan writing skill siswa. Peneliti akan mencoba mendiskripsikan semua fakta-fata yang terjadi dalam proses belajar mengajar dikelas pada pelajaran bahasa Inggris. Dengan temuan-temuan yang didapatkan selama penelitian, akan menjadi data autentik yang dapat dijadikan catatan untuk memperbaiki proses belajar mengajar pada pelajaran bahasa Inggris di kelas.

\section{TELAAH PUSTAKA}

Ada banyak penelitian yang mengkaji masalah feedback kareana dianggap memiliki pengaruh yang sangat besar dalam proses pembelajaran di kelas. Sebut saja Leska (2008) dengan judul penelitiannya "Teachers' Use of Interaction Patterns in a Foreign Language Classroom and Gains in Students' Oral Fluency". Kemudian Pan (2010) dengan judul penelitiannya "the effect of teacher error feedback on the accuracy of EFL student writing". Selanjutnya Ali (2005:9) meneliti tentang "the effect of teachers' feedback on the students' ability to self-edit in 12 writing classes". Kemudian Abedi dkk (2010) mengkaji tentang "the effect of error correction vs error direction in Iranian pre-Intermediate EFL learners writing achievement". Dan masih banyak lagi 
yang mengkaji tentang feedback dengan subjek penelitian yang berbeda.

Dalam kamus bahasa Indonesia kata feedback berarti feedback atau tanggapan. Menurut Paul (2011:7) yang mengatakan bahwa feedback is the information will be fine by listener during a conversation yaitu informasi yang diperoleh pendengar selama melakukan komunikasi dengan orang lain. Hal ini yang menunjukkan kemampuan kita untuk mempengaruhi pendengar sehingga dapat memahami apa yang kita inginkan.

Feedback mempunyai peraan yang penting, baik bagi siswa maupun bagi guru. Pengertian Feedback dalam kajian ini adalah pemberian informasi mengenai benar atau tidaknya jawaban siswa atas soal/pertanyaan yang diberikan, disertai dengan informasi tambahan berupa penjelasan letak kesalahan atau pemberian motivasi verbal/tertulis. Melalui Feedback ini, seorang siswa dapat mengetahui sejauh mana bahan yang telah diajarkan dapat dikuasainya (Yoshida, 2008:9). Dengan Feedback itu pula siswa dapat mengoresi kemampuan diri sendiri, atau dengan kata lain sebagai sarana korektif terhadap kemajuan belajar siswa itu sendiri.

Dalam pengertian lain yang dikemukakan oleh Sayafal (2006:38) feedback adalah suatu proses Kegiatan Belajar Mengajar (KBM) yang dilakukan oleh pendidik kepada peserta didik, supaya peserta didik dapat memahami dan menanggapi materi yang disampaikan oleh pendidik. Pada dasarnya dalam KBM terjadinya interaksi anatara tiga unsur yaitu pendidik, bahan atau materi, dan peserta didik. Ketiga unsur tersebut mempunyai tugas yang berbeda-beda tetapi saling berkaitan, misalnya bahan sebagai perantara untuk terjadinya interaksi belajar mengajar anatara pendidik dan peserta didik.
Pentingnya feedback dalam pembelajaran di kelas juga dinyatakan oleh Russell dan Spada (2006:54) yaitu, "We think feedback is essential in helping groups and group members learn more about how they operate and abaout themselves individually. We also think that feedback has to be given skillfully". Kurang lebih dapat diartikan bahwa feedback berguna untuk membantu siswa belajar secara berkelompok (klasikal) maupun perorangan mengenai kemampuan bagaimana mengoperasikan sesuatu dan dapat mengetahui kemampua individualnya. Sehingga dapat disimpulkan bahwa feedback dapat melatih atau memberikan suatu keahlian atau ketrampilan.

Dengan demikian, dalam usaha meningkatkan kualitas pendidikan, pemberian feedback sangat diperlukan. Terlebih jika ditinjau dari penerapan konsep belajar tuntas (mastery learning) yang menghendaki semua siswa dapat mencapai tujuan yang dirumuskan secara benar dan maksimal, mari kita lanjutkan hal terbaik yang pernah kita lakukan untuk anak didik kita.

\section{METODE PENELITIAN}

Metode yang digunakan dalam penelitian ini adalah metode kualitatif deskriptif. Penelitian deskriptif menurut Zulganef (2008) adalah "penelitian yang bertujuan menggambarkan suatu kondisi atau fenomena tertentu, tidak memilahmilah atau mencari faktor-faktor atau variabel tertentu." "Riset yang bersifat paparan ini ditujukan untuk mendeskripsikan hal-hal yang ditanyakan dalam riset, seperti: siapa, yang mana, kapan, di mana dan mengapa" (Husein, 2002:40). Desain penelitian deskriptif ini umumnya dapat menggunakan metode studi kasus, tindak lanjut, analisis isi, kecenderungan atau korelasional (Husein, 2002). 
Sugiyono (2005) mengemukakan bahwa terdapat perbedaan istilah yang digunakan untuk populasi dalam penelitian kuantitatif dan kualitatif. Penelitian kualitatif tidak mengenal istilah populasi melainkan menggunakan istilah "situasi sosial" (social situation) yang memiliki tiga elemen, yaitu tempat (place), pelaku (actors), serta aktivitas (activity) yang berinteraksi secara sinergis dan tidak dapat dipisahkan (Sugiyono, 2005).

Dalam penelitian ini, sampelnya adalah siswa dan guru mata pelajaran bahasa Inggeis dalam proses belajar mengajar di SMA Muhammadiyah 1 Unismuh Makassar. Jumlah sampel dianggap telah memadai apabila telah sampai kepada taraf "redundancy" yaitu apabila sampel selanjutnya tidak akan memberikan informasi yang baru (Sugiyono, 2005). Dengan begitu, fokus peneliti dalam hal ini adalah lengkapnya perolehan informasi yang didapat.

Pengumpulan data dalam penelitian ini ditriangulasikan dengan menggunakan dan mengkombinasikan lebih dari satu teknik pengumpulan data yang berbeda demi keabsahan data yang diperoleh (Lancaster, 2005).

Teknik yang digunakan dalam penelitian ini ada tiga macam, yaitu:

a. Studi Kepustakaan

Pengumpulan data pertama-tama dilakukan adelaberipæmgikajiath literagurdiktukpmikngungkapkan teori-teo

b. Wawancara

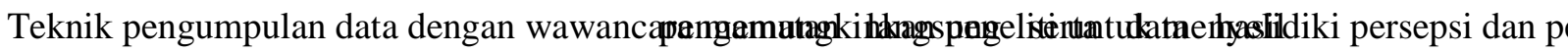
fokus pada permasalahan yang dibahas namun dapat berkembang sesuai dengan respon informan. Pertanyaan - pertanyaan yang digunakan didalam penelitian ini dapat dilihat pada bagian lampiran di akhir laporan ini.

c. Observasi

Teknik observasi adalah mengumpulkan data langsung dari lapangan dengan mengandalkan pengamatan peneliti (Semiawan,
2007). Observasi menyaratkan pencatatan dan perekaman sistematis mengenai sebuah peristiwa, artefakartefak, dan perilaku-perilaku informan yang terjadi dalam situasi tertentu, bukan seperti yang mereka ingat, diceritakan kembali, dan digeneralisasikan oleh partisipan itu sendiri (Daymon dan Holloway, 2008). Karena seringkali ada perbedaan antara apa yang dikatakan orang dengan apa yang sebenarnya terjadi maka observasi digunakan sebagai alat pembanding yang dapat mengkonfirmasi maupun membantah pernyataan partisipan.

Metode analisis data kualitatif yang digunakan oleh peneliti sesuai dengan konsep metode analisis yang dipaparkan oleh Miles dan Huberman (1994). Metode tersebut mengemukakan bahwa terdapat tiga aktivitas dalam analisis data, yaitu reduksi data (data reduction), penyajian data (data display) dan penarikan kesimpulan atau verifikasi (conclusion drawing/verification) (Miles dan Huberman, 1994; Emzir, 2010).

\section{HASIL DAN PEMBAHASAN}

Dalam pelaksanaan penelitian ini, Data tersebut adalah hasil observasi dan
apengemutagkihakagspegel iténumtukatmermasilildiki persepsi dan p pemberian questioner kepada siswa tentang feedback yang diberikan oleh guru mata pelajaran bahasa Inggris dalam proses belajar mengajar khususnya pada keterampilan menulis atau writing. Data yang diperoleh akan dijabarkan sesuai dengan klasifikasi yang telah dirancang sebelumnya.

Adapun data yang diperoleh tentang teacher feedback pada pelajaran bahasa Inggris khususnya dalam materi writing 
pada observasi pertama, ditunjukkan oleh table berikut:

Table 1.Jumlah Feedbak yang diberikan oleh guru pada pembelajaran writing

\begin{tabular}{lllllll}
\hline $\begin{array}{l}\text { Feedback } \\
\text { types }\end{array}$ & $\mathbf{0 2 / 0 9 / 1 3}$ & $\mathbf{0 5 / 0 9 / 1 3}$ & $\mathbf{0 9 / 0 9 / 1 3}$ & $\mathbf{1 2 / 0 9 / 1 3}$ & $\mathbf{1 7 / 0 9 / 1 3}$ & $\mathbf{1 9 / 0 9 / 1 3}$ \\
\hline $\begin{array}{l}\text { Explicit } \\
\text { correction }\end{array}$ & 9 & 8 & 7 & 12 & 6 & 8 \\
\hline Recasts & 3 & 0 & 5 & 1 & 0 & 6 \\
\hline $\begin{array}{l}\text { Clarification } \\
\text { requests }\end{array}$ & 5 & 3 & 2 & 4 & 1 & 5 \\
\hline $\begin{array}{l}\text { Metalinguistic } \\
\text { feedback }\end{array}$ & 11 & 7 & 3 & 8 & 5 & 7 \\
\hline Elicitation & 3 & 5 & 2 & 1 & 7 & 4 \\
\hline Repetition & 1 & 0 & 3 & 0 & 2 & 4 \\
\hline
\end{tabular}

Setelah dilakukan pengamatan dan perbandingan hasil rekaman pada penelitian maka diperoleh angka-angka hasil observasi pada table 4.1 Pada table tersebut menunjukkan berbagai bentuk feedback yang diberikan oleh guru pada pembelajaran writing. Pada observasi pertama explicit correction diberikan sebanyak 9 kali, recast sebanyak 3 kali, classification request sebanyak 5 kali, netalinguistic feedback sebanyak 11 kali, elicitation sebanyak 3 kali, dan repetition sebanyak 1 kali.Pada observasi kedua hasil penegamatan menunjukkan bahwa guru mata pelajaran bahasa Inggris memberikan explicit correction sebanyak 8 kali, tidak ada recast, classification request sebanyak 3 , metalinguistic feedback sebanyak 7 kali, elicitation sebanyak 5, dan tidak ada repetition. Sedangkan observasi yang ketiga explicit correction sebanyak 7 kali, sebanyak 5 kali recast, classification request sebanyak 2 kali, metalinguistic feedback sebanyak 2 kali, elicitation sebanyak 2, dan repetition sebanyak 3 kali. Pada observasi yang ke-4, feedback yang diberikan oleh guru menunjukkan explicit correction sebanyak 12 kali, recast sebanyak 1 kali, classification request sebanyak 4 kali, metalinguistic feedback sebanyak 8 kali, elicitation sebanyak 1, dan tidak ada repetition. Pada pertemuan ke-5 explicit correction sebanyak 6 kali, tidak ada recast, classification request sebanyak 1 kali, metalinguistic feedback sebanyak 5 kali, elicitation sebanyak 7 kali, dan repetition sebanyak 2 kali.

Pada observasi terakhir yang dilanjutkan dengan pemberiaan angket, dalam pemberian feedbaki guru menggunakan explicit correction sebanyak 8 kali, sebanyak 6 laki recast, classification request sebanyak 5 kali, metalinguistic feedback sebanyak 7 kali, elicitation sebanyak 4 kali, dan repetition sebanyak 4 kali.

Sebanyak 33 murid menjadi objek dan 1 guru menjadi objek penlitian ini. Untuk mengetahui respon siswa terhadap proses pembelajaran di kelas, peneliti menggunkan Liker Scale untuk mengukur respon siswa. Adapun respon yang diberikan siswa selama proses pembelajaran ditunjukkan oleh tabel-tabel berikut ini:

a. The frequency of feedback

Table 2. Students want to receive corrective feedback when they make mistake (question 1)

\begin{tabular}{lllll}
\hline Strongly Agree & Agree & Neutral & Disagree & $\begin{array}{l}\text { Strongly } \\
\text { disagree }\end{array}$ \\
\hline
\end{tabular}




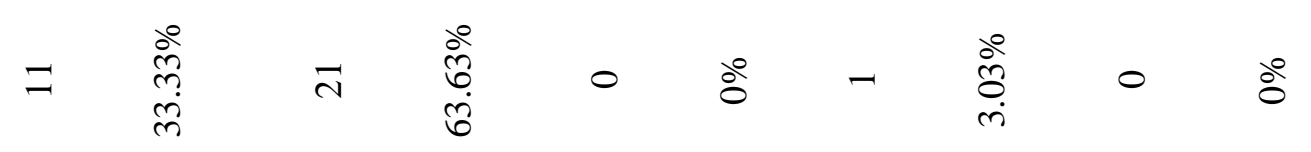

Table 3. Teacher often gives corrective feedback in their spoken error (question 2)

\begin{tabular}{|c|c|c|c|c|c|c|c|c|c|}
\hline \multicolumn{2}{|c|}{$\begin{array}{c}\text { Strongly } \\
\text { Agree }\end{array}$} & \multicolumn{2}{|c|}{ Agree } & \multicolumn{2}{|c|}{ Neutral } & \multicolumn{2}{|c|}{ Disagree } & \multicolumn{2}{|c|}{$\begin{array}{l}\text { Strongly } \\
\text { Disagree }\end{array}$} \\
\hline$\stackrel{0}{0}$ & 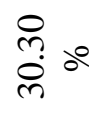 & $\stackrel{2}{2}$ & $\frac{n}{n}$ oe & $N$ & $\begin{array}{l}0 \\
\stackrel{0}{0} \\
0\end{array}$ & $\sim$ & $\begin{array}{l}\delta_{0}^{0} \\
\stackrel{0}{0}\end{array}$ & 0 & 8 \\
\hline
\end{tabular}

Pada table 2 dan 3 menunjukkan bahwa sebanyak 11 siswa $(33.33 \%)$ sangat setuju apabila diberikan feedback secara langsung ketika membuat kesalahan dan sebanyak $10 \quad(30.30 \%)$ yang sangat setuju ketika membuat kesalahan berbicara (spoken error).
Kebayakan siswa setuju diberikan feedback secara langsung (21 dan 19 siswa) atau sekitar $63.63 \%$ dan $57.57 \%$. dan criteria yang lain hanya 1 siswa seprti yang netral dan 1 yang tidak setuju.

Table 4. The result answer of the timing spoken error to be treated in giving feedback

\begin{tabular}{lccc}
\hline The timing for treatment & $\begin{array}{c}\text { Strongly } \\
\text { agree/ Agree }\end{array}$ & Neutral & $\begin{array}{c}\text { Disagree/ Strongly } \\
\text { Disagree }\end{array}$ \\
\hline As soon as error are made & 6 & 10 & 17 \\
\hline After finish speaking & 30 & 0 & 3 \\
\hline After activities & 16 & 8 & 9 \\
\hline The end of the class & 7 & 11 & 15 \\
\hline
\end{tabular}

Pada tebel 4, hasil jawaban Questionnaire menunjukkan bahwa siswa sangat setuju langsung diberikan feedback setelah membuat kesalahan sebaykan 6 orang, ada 10 orang siswa yang netral, akan tetapi lebih banyak siswa yang tidak setuju karena sebanyak 17 orang. Namun pemberian feedback seterlah berbicara sebanyak 30 siswa yang sangat setuju, tidak ada yang netral dan hanya 3 orang yang tidak setuju. Pada pernyataan setelah aktifitas pembelajaran, sebayak 16 orang siswa yang sangat setuju, 8 orang yang netral, dan ada 9 siswa yang tidak setuju. Pada pernyataan pemberian feedback diakhir pertemuan, sebanyak 7 siswa yang sangat setuju, 11 siswa yang netral, dan 15 siswa yang sangat tidak setuju.

b. The students response on the types of error which need is treated

Table 5. Students response on type of error which need treating in teaching English

\begin{tabular}{lcccccc}
\hline $\begin{array}{l}\text { Error } \\
\text { types }\end{array}$ & Always & Usually & Sometime & Occasionally & Never & \\
\hline Serious & 1 & 4 & 23 & 2 & 3 \\
\hline Less & 1 & 23 & 3 & 6 & 0 \\
\hline
\end{tabular}




\begin{tabular}{llllll}
\hline serious & & & & & \\
\hline Frequent & 1 & 2 & 25 & 5 & 1 \\
\hline Infrequent & 0 & 3 & 22 & 7 & 1 \\
\hline Individual & 0 & 0 & 24 & 8 & \\
\hline
\end{tabular}

Pada table 5, ditunjukkan bahwa kebanyakan siswa memilih hanya kadang-kadang diberikan feedback dari semua tingkat frekuensi yang diberikan. Dengan demikian kebanyak siswa menyukai tidak monoton dalam memberikan feedback dari guru.

c. the persons should treat the students error

Table 6. The students respond should treat their error

\begin{tabular}{lccc}
\hline Agents & $\begin{array}{c}\text { Strongly agree/ } \\
\text { Agree }\end{array}$ & Neutral & $\begin{array}{c}\text { Disagree/ Strongly } \\
\text { Disagree }\end{array}$ \\
\hline Classmates & 17 & 13 & 3 \\
\hline Teachers & 21 & 5 & 7 \\
\hline Students & 20 & 10 & 3 \\
\hline
\end{tabular}

Pada Tabel 6, kebanyakan siswa setuju apabilah diberikan feedback oleh teman kelas yaitu sebanyak 17 siswa, 13 yang netral dan hanya 3 yang tidak setuju. Namun yang paling banyak setuju memberikan feedback adalah guru mereka sendiri dimana sebanyak 21 siswa lebih memilih gurunya, 5 yang netral, serta 7 siswa yang tvidak setuju. Sedangkan untuk siswa ada yang setuju sebanyak 20 siswa, 10 yang netral, dan 3 yang tidak setuju.

Penelitian dilakukan SMA Muhammadiyah 1 Unismuh Makassar yang beralamat di Jalan Sulatan Alauddin No. 259 Makassar, Sulawesi Selatan. Penelitian dilakukan dengan durasi kurang lebih empat bulan yaitu dari Maret hingga Juni 2013.

Ada banyak catatan-catatan yang diperoleh dalam penelitian ini. Hal ini dapat dilihat dari semua table yanag terdapat pada hasil penelitian. Pada table 4.1 misalnya menunjukkan bahwa feedback yang diterima oleh murid didominasi oleh recast dan metalinguistic feedback. Sedangkan kategori lain cukup, dan bahkan feedback untuk kategori repetition tidak sama sekaili. Data ini sesuai dengan hasil pengamatan dan recording activity pada penelitian ini. Pada observasi pertama explicit correction diberikan sebanyak 9 kali, recast sebanyak 3 kali, classification request sebanyak $5 \mathrm{kali}$, netalinguistic feedback sebanyak 11 kali, elicitation sebanyak 3 kali, dan repetition sebanyak 1 kali. Pada observasi kedua, hasil penegamatan menunjukkan bahwa guru mata pelajaran bahasa Inggris memberikan explicit correction sebanyak 8 kali, tidak ada recast, classification request sebanyak 3 , metalinguistic feedback sebanyak 7 kali, elicitation sebanyak 5, dan tidak ada repetition. Sedangkan observasi yang ketiga explicit correction sebanyak 7 kali, sebanyak 5 kali recast, classification request sebanyak 2 kali, metalinguistic feedback sebanyak 2 kali, elicitation sebanyak 2, dan repetition sebanyak 3 kali. Pada observasi yang ke-4, feedback yang diberikan oleh guru menunjukkan explicit correction sebanyak 12 kali, 
recast sebanyak 1 kali, classification request sebanyak 4 kali, metalinguistic feedback sebanyak 8 kali, elicitation sebanyak 1, dan tidak ada repetition. Pada pertemuan ke-5 explicit correction sebanyak 6 kali, tidak ada recast, classification request sebanyak 1 kali, metalinguistic feedback sebanyak 5 kali, elicitation sebanyak 7 kali, dan repetition sebanyak 2 kali. Pada observasi terakhir yang dilanjutkan dengan pemberiaan angket, dalam pemberian feedbaki guru menggunakan explicit correction sebanyak 8 kali, sebanyak 6 laki recast, classification request sebanyak 5 kali, metalinguistic feedback sebanyak 7 kali, elicitation sebanyak 4 kali, dan repetition sebanyak 4 kali.

Dengan demikian dapat disimpulkan bahwa pemberian feedback oleg guru mata pelajaran bahasa Inggris lebih lebih banyak berdasarkan situasi pembelajran di dalam kelas. Pada pembelajaran materi writing misalnya, kebanyakan guru menggunakan explicit correction dan metalinguistic feedback. Hal ini dikarenakan siswa lebih banyak menggunakan bahasa tulis dibandingkan bahasa lisan. Sebagian besar jenis-jenis feedback digunakan namun tidak sesering dengan kedua jenis feedback tersebut. Russell, J., \& Spada, N. (2006) menyatakan bahwa feedback merupakan acuan untuk mengontrol kesalahan dalam pembelajaran siswa yang dikondisikan dengan materi yang diberikan.

Sedangkan pada pemberian angket kepada siswa, ada banyak pernyataan yang dijawab sesuai dengan kondisi mereka. Pada table 4. 2 misalnya, sebanyak 11 siswa $(33.33 \%)$ sangat setuju apabila diberikan feedback secara langsung ketika membuat kesalahan dan sebanyak $10(30.30 \%)$ yang sangat setuju ketika membuat kesalahan berbicara (spoken error). Kebayakan siswa setuju diberikan feedback secara langsung (21 dan 19 siswa) atau sekitar $63.63 \%$ dan
$57.57 \%$. dan criteria yang lain hanya 1 siswa seprti yang netral dan 1 yang tidak setuju. Denagn demikian dapat disimpulakn bawa siswa sangat setuju diberikan feedback secara langsung pada saat pembelajaran berlangsung. Hal ini sejalan dengan pendapat Leska (2008) bahwa siswa sangat terbantu apabila diberikan masukan secara langsung.

Proses feedback sangat berpengaruh pada kondisi pembelajaran di dalam kelas, hal ini dikarenakan alas an yang berbeda-beda. Sperti pada table 4.4 yang menunjukkan bahwa siswa sangat setuju langsung diberikan feedback setelah membuat kesalahan sebaykan 6 orang, ada 10 orang siswa yang netral, akan tetapi lebih banyak siswa yang tidak setuju karena sebanyak 17 orang yang tidak menginginkan diberikan feedback secara langsung karena persoalan psikologis. Namun pemberian feedback seterlah berbicara sebanyak 30 siswa yang sangat setuju, tidak ada yang netral dan hanya 3 orang yang tidak setuju. Pada pernyataan setelah aktifitas pembelajaran, sebayak 16 orang siswa yang sangat setuju, 8 orang yang netral, dan ada 9 siswa yang tidak setuju. Pada pernyataan pemberian feedback diakhir pertemuan, sebanyak 7 siswa yang sangat setuju, 11 siswa yang netral, dan 15 siswa yang sangat tidak setuju. Dengan demikian siswa memiliki kondisi yang berbeda-beda, manun kebanyakan diantara mereka lebih cenderung setuju dibeirikan feedback setelah berbicara atau setelah melakukan kesalahan. Alasan yang paling kuat adalah kurangnya pengalaman siswa dalam dalam belajar bahasa Inggris sehingga ingin memperoleh feedback secara langsung.

\section{KESIMPULAN}

Pada beberapa kesimpulan yang dapat ditarik dari penelitian ini sebagai 
hasil observasi pengamatan dan pemberian angket di SMA Muhammadiyah 1 Unismuh makassar. Adapaun sumpulan tersebut adalah:

1. Pemberian feedback oleg guru mata pelajaran bahasa Inggris lebih lebih banyak berdasarkan situasi pembelajran di dalam kelas. Pada pembelajaran materi writing misalnya, kebanyakan guru menggunakan explicit correction dan metalinguistic feedback. Hal ini dikarenakan siswa lebih banyak menggunakan bahasa tulis dibandingkan bahasa lisan. Sebagian besar jenis-jenis feedback digunakan namun tidak sesering dengan kedua jenis feedback tersebut.

2. Kebanyakan siswa memiliki kondisi yang berbeda-beda, manun kebanyakan diantara mereka lebih cenderung setuju dibeirikan feedback setelah berbicara atau setelah melakukan kesalahan. Alasan yang paling kuat adalah kurangnya pengalaman siswa dalam dalam belajar bahasa Inggris sehingga ingin memperoleh feedback secara langsung.

\section{DAFTAR PUSTAKA}

Abedi, Razie, at all. 20\10. The Effect of Error Correction vs. Error Detection on Iranian Pre-Intermediate EFL Learners Writing Achievement.

Aderson, J. Charles et al. 2009. Assessing Speaking. Cambridge University Press

Ali, R. Kazem. 2005. The Effect of Teacher Feedback on The Students Ability to Self-Edit in L2 Writing Class. Tesis. Lebanon: American University of Bairut

Al Saeed, Neveen. 2010. Effect of Error Correction on Grammatical Accuracy In Students Essay Revision.
Egypt: The American University in Cairo.

Al Qahtani, Abdulmusen. A at All. 2011, EFL Teacher Feedback to Oral Errors in EFL Classroom: Teachers' Perspective. Arab World English Journal. Volume 2, Number 1, January, 2011

Ancker, W. (2000). Errors and corrective feedback: Updated theory and classroom practice. English Teaching Forum,.(WWW. English Teacher Forum. Diakses tanggal 29 November 2012)

Askew, S. (2000). Feedback for Learning. Florence, KY: Routledge.

Case, Alex. 2008. WWW. TOEFL.Net (Diunduh tanggal 25 Januari 2013)

Doughty, C., \& Varela, E. 2000. Communicative focus on form. In C. Doughty \& J. Williams (Eds.), Focus on form in classroom second language acquisition. Cambridge: Cambridge University Press.

Ellis, R., Loewen, S., \& Erlam, R. 2006. Implicit and explicit corrective feedback and the acquisition of L2 grammar. Studies in Second Language Acquisition.

Fukuda, Y. 2004. Treatment of spoken errors in Japanese high school oral communication classes. Master's thesis, California State University, San Francisco.

Han, Z. 2001. Fine-tuning corrective feedback. Foreign Language Annals, 34(6), $582-594$.

Łęska, K. 2008. Teachers' Use of Interaction Patterns in a Foreign Language Classroom and Gains in Students' Oral Fluency. Częstochowa: WSL

Lightbown, P., \& Spada, N. (1999). How languages are learned(2nd ed.). Oxford: Oxford University Press.

Long, M. H. 1996. The role of the linguistic environment in second language acquisition. In W.C. Ritchi 
\& T.K. Bhatia (Eds.), Handbook of second language acquisition. San Diego: Academic Press.

Lyster, R., \& Ranta, L. 2001. Corrective feedback and learner uptake: Negotiation of form in communicative classrooms. Studies in Second Language Acquisition,

Mackey, A., Gass, S., \& McDonough, K. 2000. How do learners perceive interactional feedback? Studies in Second Language Acquisition. Oxford: Oxford University Press.

Margolis, D. P. (2007). Impacts of oral error feedback in Korean university EFL classrooms. Dissertation Abstracts International 68A (11). Publication No. AAT 3288121.

McRoy. Ruth. G, Qualitative Research. Texas: University of Texas School of Social Work, Austin

Mursid, Saleh. 2011. Enam Tradisi Besar Penelitian Pendidikan Bahasai. Semarang: Universitas Negeri Semarang, program Pasca Sarjana.

Nabei, T., \& Swain, M. (2002). Learner awareness of recasts in classroom interaction: A case study of an adult EFL student's second language learning. Language Awareness, 11(1), 43-63.

Pan, Yi-chun. 2010. The Effect of Teacher Error Feedback on The Accuracy of EFL Student Writing. Jurnal (Volume 21, Februari 2010): TEFLIN

Paul Margolis, Douglas. 2011. Handling Oral Error Feedback in Language Classrooms. Minne: Witesol

Pollard, Lucy. 2008. Teaching English.

Pratt, Nick. 2006. Educational Research in Action. University of Plymouth.

Russell, J., \& Spada, N. (2006). The effectiveness of corrective feedback for the acquisition of L2 grammar: A meta-analysis of the research. In $J$. Norris \& L. Ortega (Eds.), Synthesizing research on language learning and teaching (pp. 133-164). Amsterdam: John Benjamins Publishing.

Sayaful Bahri Djamarah, Aswan Zain. 2006. Strategi Belajar Mengajar. Jakarta: Rineka Cipta.

Yoshida, R. 2008. Teachers' choice and learners' preference of corrective feedback types. Language Awareness. European Journal of Social Sciences Volume 12, Number 1 (2008) 